DOI: https://doi.org/10.47405/mjssh.v6i8.963

\begin{tabular}{|c|c|}
\hline 4 & Malaysian Journal of Social Sciences and Humanities (MJSSH) \\
\hline $\begin{array}{l}\text { Malaysian Juoural of } \\
\text { Social ccciecces and }\end{array}$ & Volume 6, Issue 8, August 2021 \\
\hline (MJ-sSH) & e-ISSN : 2504-8562 \\
\hline & $\begin{array}{l}\text { Journal home page: } \\
\text { www.msocialsciences.com }\end{array}$ \\
\hline
\end{tabular}

\title{
Motivasi dan Tahap Aktiviti Fizikal Semasa COVID-19
}

Nurulhuda Amirah Mohd Zakari'1, Tajul Arifin Muhamad1

${ }^{1}$ Fakulti Pendidikan, Universiti Kebangsaan Malaysia (UKM)

Correspondence: Nurulhuda Amirah Mohd Zakari (p104140@siswa.ukm.edu.my)

\begin{abstract}
Abstrak
Dunia mengalami cabaran yang luar biasa hingga mengubah kehidupan normal manusia kepada norma baharu. Pengasingan sosial, penjarakan fizikal dan perintah kawalan pergerakan disebabkan oleh penyakit berjangkit koronavirus 2019, pandemik Covid-19 telah mengakibatkan penurunan tahap aktiviti fizikal bagi kedua-dua jantina. Pengenal pastian faktor motivasi atau pemangkin kepada melakukan aktiviti fizikal akan dapat menyumbang kepada institusi berkaitan dalam merangka strategi untuk meningkatkan tahap aktiviti fizikal semasa pandemik. Kajian ini adalah untuk mengenal pasti faktor motivasi intrinsik dan ekstrinsik yang mempengaruhi penglibatan pelajar program Pendidikan Sukan dan Rekreasi (SUKRES), Universiti Kebangsaan Malaysia (UKM) dalam aktiviti fizikal semasa pandemik COVID-19. Kajian berbentuk kuantitatif menggunakan instrumen soal selidik yang diadaptasi dari "Exercise Motivation Inventory" (EMI) dan "Global Physical Activity Inventory" (GPAQ) dan dianalisis menggunakan perisian "Statistical Package for Social Science" (SPSS) versi 23.0. Kajian keratan rentas ini dijalankan semasa dalam perintah kawalan pergerakan bersyarat (PKPB) merangkumi pelajar SUKRES UKM dari Tahun 1 hingga Tahun 4 yang sedang mengikuti pengajian secara atas talian "online distance learning" dan maklumat diperoleh menggunakan edaran soal selidik secara atas talian "google form". Secara keseluruhan kajian menunjukkan majoriti pelajar Sukan dan Rekreasi Universiti Kebangsaan Malaysia kurang melibatkan diri dalam aktiviti fizikal dan tidak terdapat perbezaan yang signifikan dalam perbandingan min antara faktor motivasi intrinsik dan ekstrinsik berdasarkan jantina namun didapati pelajar lelaki lebih bermotivasi intrinsik melakukan aktiviti fizikal manakala pelajar perempuan lebih bermotivasi ekstrinsik beraktiviti fizikal semasa pandemik COVID-19. Hasil kajian juga mendapati terdapat hubungan di antara motivasi ekstrinsik dan tahap aktiviti fizikal semasa pandemik yang mana boleh membantu pihak universiti dan institusi pengajian tinggi merangka strategi baharu bagi menggalakkan orang awam khususnya pelajar untuk terus melakukan aktiviti fizikal walaupun berdepan dengan wabak pandemik seperti mempromosikan pengamalan gaya hidup sihat di rumah dengan akses kepada fasiliti sedia ada di persekitaran rumah masing-masing.
\end{abstract}

Kata kunci: motivasi intrinsik, motivasi ekstrinsik, aktiviti fizikal, pandemik, COVID-19

\section{Motivation and Level of Physical Activity During COVID-19}

\begin{abstract}
The world is facing an incredible challenge to change normal human life to a new norm. Social isolation, physical incarceration and movement control orders due to the 2019 coronavirus infectious disease, the Covid-19 pandemic have resulted in decreased levels of physical activity for both sexes. Identifiers of motivational factors or catalysts to perform physical activity will be able to contribute to
\end{abstract}


relevant institutions in formulating strategies to increase the level of physical activity during a pandemic. This study was to identify the intrinsic and extrinsic motivational factors that influence the involvement of students of the Sports and Recreation Education (SUKRES) program, Universiti Kebangsaan Malaysia (UKM) in physical activity during the COVID-19 pandemic. Quantitative study using a questionnaire instrument adapted from the "Exercise Motivation Inventory" (EMI) and "Global Physical Activity Inventory" (GPAQ) and analyzed using the software "Statistical Package for Social Science" (SPSS) version 23.0. This cross -sectional study was conducted during the conditional movement control order (PKPB) covering SUKRES UKM students from Year 1 to Year 4 who are studying online distance learning and information was obtained using online questionnaire distribution "google form" . Overall, the study showed that the majority of Universiti Kebangsaan Malaysia Sports and Recreation students were less involved in physical activities and there was no significant difference in the mean comparison between intrinsic and extrinsic motivation factors based on gender but found that male students were more intrinsically motivated to do physical activities while female students were more motivated. extrinsic physical activity during the COVID-19 pandemic. The study also found that there is a relationship between extrinsic motivation and the level of physical activity during the pandemic which can help universities and institutions of higher learning formulate new strategies to encourage the public, especially students to continue physical activity despite the pandemic epidemic such as promoting lifestyle practices. healthy at home with access to existing facilities in their respective home environment.

Keywords: intrinsic motivation, extrinsic motivation, physical activity, pandemic, COVID-19

\section{Pengenalan}

Pengumuman kecemasan Sekatan Pergerakan atau PKP yang diumumkan oleh kerajaan pada 18 Mac 2020 menyebabkan perubahan besar dalam norma hidup individu khususnya dalam aktiviti fizikal dan sesi latihan sukan. Kebanyakan negara turut mengambil langkah melaksanakan Perintah Kawalan Pergerakan (PKP) bagi membendung penularan wabak COVID-19 seperti yang dilakukan oleh wilayah Republik Cameroon (Ikomey \& George, 2020) yang mengenakan perintah pengasingan sosial atau penjarakan fizikal yang bertujuan untuk memutuskan rantaian jangkitan COVID-19 (Hellewell et al., 2020). Penerapan strategi pengasingan yang ketat untuk membendung penyebaran virus telah menimbulkan kegelisahan serta risiko faktor kemurungan dalam kalangan populasi dunia (Burtscher J, Burtscher M, \& Millet GP, 2020).

Di Malaysia, pengumuman Perintah Kawalan Pergerakan (PKP) oleh kerajaan sejajar dengan penutupan premis-premis kerajaan dan swasta serta sektor yang tidak tergolong dalam perkhidmatan penting bagi negara turut menimbulkan kegelisahan dalam kalangan masyarakat secara amnya. Ini termasuklah taman permainan dan pusat rekreasi yang berfungsi sebagai tempat riadah dan melakukan aktiviti fizikal (Barkley, 2020) bagi masyarakat di samping penutupan sektor sukan seperti gimnasium serta kemudahan awam yang biasanya berfungsi sebagai tempat beraktiviti bersama rakan mahupun keluarga. Hal ini mengakibatkan masyarakat mungkin mengalami tekanan dan memiliki lebih sedikit peluang untuk kekal aktif secara fizikal (Hall et al., 2020) walaupun "World Health Organization" (WHO) menyatakan aktiviti fizikal memberikan manfaat kesihatan yang tinggi kepada jantung, minda dan badan serta meningkatkan kesejahteraan individu secara holistik (WHO, 2019).

Aktiviti fizikal menjadi faktor pelindung utama bagi pelbagai jenis penyakit tidak berjangkit dan meningkatkan kesihatan dan kesejahteraan kehidupan (WHO, 2019). WHO telah menyarankan golongan dewasa melakukan 150 minit aktiviti fizikal berintensiti sederhana atau 75 minit aktiviti fizikal berintensiti kuat dalam seminggu atau 500-1000 nilai persamaan metabolik (MET) minit seminggu (WHO,2020). Namun demikian didapati masih terdapat kira-kira $31 \%$ golongan dewasa tidak mencapai aktiviti fizikal yang mencukupi walaupun ia dilihat sebagai perkara yang sangat penting (Kohl et al., 2012) dalam meningkatkan kualiti hidup selain meningkatkan tahap kesihatan tanpa mengira umur dan status individu. Tambahan lagi, kemunculan pandemik COVID-19 telah mengakibatkan penurunan aktiviti fizikal (Hall et al., 2020) yang mendadak kerana masyarakat 
beranggapan mereka mempunyai lebih sedikit peluang untuk melakukan aktiviti fizikal akibat perintah pengasingan sosial atau isolasi yang dikenakan oleh pihak Majlis Keselamatan Negara (MKN).

Pandemik COVID-19 yang disebabkan oleh koronavirus sindrom pernafasan akut teruk 2 (SARS-CoV2) dan merupakan penyakit berjangkit yang merebak melalui titisan pernafasan dari batuk atau bersin seseorang (WHO, 2020). Kaedah penghantaran utamanya adalah melalui titisan pernafasan dengan masa inkubasi (1-14 hari) yang serupa dengan koronavirus sindrom pernafasan akut yang teruk (SARSCoV-1) (Emerenci et al., 2020). Penyakit ini merebak dari manusia ke manusia dengan sangat cepat dan telah mencatatkan jumlah kematian yang sangat tinggi. Mereka yang membawa virus ini biasanya mengalami simptom radang paru-paru dengan gejala seperti demam, batuk dan kesukaran bernafas. Kebanyakan negara telah mengambil langkah proaktif bagi membendung penularan wabak dari terus berlaku dengan kerjasama antara semua pihak termasuk kerajaan mahupun swasta. Antaranya adalah dengan menutup premis kerajaan mahupun swasta dalam sesuatu tempoh yang telah ditetapkan kecuali sektor penting negara seperti makanan, peruncitan, keselamatan, kesihatan dan air (Malaysia Kini News, 16 Mac 2020). Perintah kawalan pergerakan (PKP) yang dilaksanakan oleh kerajaan ini secara tidak langsung telah mengehadkan pergerakan orang ramai dari terus beraktiviti dan ramai yang berpendapat mereka mungkin mempunyai lebih sedikit peluang untuk melakukan aktiviti fizikal apabila berada dalam situasi pandemik COVID-19.

Pendorong untuk terus konsisten dalam melakukan aktiviti fizikal walaupun berdepan dengan cabaran pandemik COVID-19 ini mungkin disebabkan oleh desakan dalaman yang mengarah perilaku bagi mencapai matlamat yang telah ditetapkan. Desakan ini merujuk kepada istilah 'motivasi' yang didefinisikan sebagai suatu tenaga atau desakan dari dalam yang mendorong dan mengarah perilaku manusia untuk mencapai tujuan atau matlamat yang ditetapkan (Jamaris, 2010). Terdapat dua faktor utama yang boleh diambil kira iaitu faktor dalaman mahupun luaran seseorang individu. Faktor dalaman ini disebut sebagai motivasi intrinsik manakala faktor luaran dikenali sebagai motivasi ekstrinsik. Secara umumnya, motivasi merupakan sebahagian daripada faktor psikologi penting yang membantu individu untuk terus kekal aktif melakukan aktiviti fizikal.

\section{Sorotan Literatur}

Teori yang mendasari motivasi sukan untuk terus konsisten dalam melakukan aktiviti fizikal adalah keberkesanan diri atau 'Self-Determination Theory' (SDT). SDT mengarahkan faktor dalaman dan luaran yang mendorong tingkah laku (Deci \& Ryan, 1985) berterusan dalam mengamalkan gaya hidup sihat. Faktor luaran didorong oleh usaha untuk mencapai ganjaran luaran (Brown, 2006). Faktor dalaman didorong oleh ganjaran dalaman seperti minat dan motivasi yang diperoleh secara dalaman dikatakan dapat menyokong tingkah laku berterusan (Deci \& Ryan, 1985). Deci \& Ryan (1985) mencadangkan tiga keperluan psikologi utama yang diperlukan untuk mencapai tahap yang optimum dalam motivasi intrinsik, termasuklah kecekapan, hubungan dan autonomi. Kecekapan membawa maksud seseorang itu percaya akan keupayaan diri untuk terus kekal aktif melakukan aktiviti fizikal. Hubungan sosial akan diperoleh setelah mereka aktif dan melibatkan diri dalam komuniti melalui penglibatan dalam aktiviti fizikal manakala autonomi adalah kawalan individu terhadap keputusan yang berkaitan dengan aktiviti fizikal mereka.

Salah satu konstruk multidimensi SDT adalah motif aktiviti fizikal, yang merangkumi motivasi yang muncul dari dua faktor dalaman dan luaran (Ryan et al., 1997). Minat merupakan motif intrinsik dari dalaman dan keseronokan berkaitan dengan aktiviti fizikal itu sendiri. Kecekapan adalah motif intrinsik lain yang didorong oleh motivasi seseorang untuk meningkatkan atau menguasai kemahiran aktiviti fizikal yang baru (Geller k. et al., 2018). Salah satu daripada tiga motif ekstrinsik iaitu penampilan, yang memotivasikan seseorang untuk terus melakukan aktiviti fizikal kerana ingin mengembangkan, memperbaiki atau mengekalkan fizikal badan serta mengawal berat badan mereka. Kecergasan merupakan faktor ekstrinsik di mana untuk sihat, kuat dan bertenaga dan terakhir adalah faktor sosial untuk berinteraksi, bergaul bersama komuniti dan bertemu dengan orang baru semasa melakukan aktiviti fizikal. Berdasarkan SDT, individu yang menekankan motif intrinsik lebih berbanding motif ekstrinsik diharapkan dapat mengekalkan aktiviti fizikal yang sihat (Deci \& Ryan 2000). Walau 
bagaimanapun, bukti mengenai motif intrinsik menjadi tunggak utama untuk mengekalkan individu beraktiviti masih lagi tidak mempunyai ketekalan.

Kajian mengenai pengaruh motivasi dan aktiviti fizikal melaporkan bahawa kajian oleh Aziz \& Salamuddin (2018) yang dijalankan sebelum pandemik COVID_19 menyatakan pengaruh motivasi intrinsik bermotifkan kesihatan dan kecergasan dan motivasi ekstrinsik bagi motif rakan-rakan penyumbang utama kepada faktor motivasi secara umum untuk melibatkan diri dalam aktiviti fizikal. Selain itu, terdapat perbezaan yang signifikan bagi motivasi intrinsik berkaitan kesihatan dan kecergasan dan faktor tubuh badan. Bagi motivasi ekstrinsik, terdapat perbezaan yang signifikan bagi faktor keluarga berdasarkan jantina. Kajian dijalankan di Sepanyol mendapati komitmen untuk terus bersukan dipengaruhi oleh efikasi kendiri dan motivasi diri sendiri (Marta et al., 2021). Manakala hasil kajian daripada Abdul Jalil J. \& Abdul Razak M. R. (2020) mendapati faktor motivasi intrinsik dan ekstrinsik dalam kalangan staf kolej universiti Widad ialah untuk mengurangkan tekanan dan memperoleh ganjaran. Kajian lepas yang dijalankan mengenai motivasi intrinsik dan ekstrinsik terhadap aktiviti fizikal lebih tertumpu kepada kajian sebelum pandemik serta pelbagai jenis pengaruh motivasi memainkan peranan untuk terus konsisten melakukan aktiviti fizikal. Kajian ini memfokuskan untuk mengenal pasti faktor motivasi intrinsik dan ekstrinsik yang mempengaruhi tahap penglibatan aktiviti fizikal semasa pandemik COVID-19.

Oleh itu, tujuan kajian ini adalah untuk menilai tahap aktiviti fizikal pelajar Program Sukan dan Rekreasi (SUKRES) Fakulti Pendidikan, Universiti Kebangsaan Malaysia (UKM) semasa pandemik covid-19. Selain itu, pengkaji juga mengukur hubungan antara faktor motivasi intrinsik dan ekstrinsik dan tahap aktiviti fizikal pelajar. Hasil kajian ini boleh menyumbang kepada sektor pendidikan tinggi yang bertujuan untuk meningkatkan tahap aktiviti fizikal semasa pandemik. Selain itu, diharapkan kajian ini juga dapat menambah pengetahuan asas untuk menggalakkan masyarakat serta komuniti supaya meluangkan masa untuk beraktiviti supaya dapat mengekalkan kesihatan yang optimum semasa pandemik.

\section{Metod Kajian}

Kajian ini adalah penyelidikan berbentuk deskriptif yang menggunakan kaedah tinjauan untuk mengenal pasti faktor motivasi dan tahap penglibatan aktiviti fizikal oleh pelajar Program Pendidikan Sukan dan Rekreasi (SUKRES), Universiti Kebangsaan Malaysia (UKM). Kaedah persampelan yang digunakan dalam kajian ini adalah berdasarkan kepada persampelan rawak. Teknik persampelan ini memberi peluang yang sama bagi setiap individu dalam populasi untuk terpilih sebagai sampel kajian. Responden kajian ini terdiri daripada 204 pelajar SUKRES UKM $(n=103)$ terdiri daripada 103 pelajar lelaki 101 pelajar perempuan terlibat sebagai responden kajian.

Instrumen yang digunakan dalam kajian ini adalah soal selidik Global Physical Activity Questionnaire (GPAQ) versi 2.0 oleh World Health Organization (WHO, 2004) dan Exercise Motivation Inventory (EMI) yang dibentuk oleh David Markland dan Lew Hardy (1993) yang diubahsuai mengikut kesesuaian dan keperluan dalam kajian yang dijalankan. Soal selidik GPAQ mengandungi 16 item yang terdiri daripada 4 sub skala jenis aktiviti fizikal merangkumi aktiviti seharian, perjalanan atau cara bergerak, aktiviti rekreasi dan kesenggangan dan aktiviti sedentari. Soal selidik EMI mengandungi 40 item yang terdiri daripada 2 skala motivasi intrinsik dan ekstrinsik yang mempunyai 4 konstruk bagi setiap skala merangkumi kesihatan, minat dan keseronokan, kemahiran dan kepakaran dan tubuh badan (intrinsik) serta rakan-rakan, keluarga, kemudahan sukan dan peranan universiti (ekstrinsik). Setiap konstruk jenis motivasi mengandungi 5 item berdasarkan 5 skala likert bermula daripada sangat tidak setuju, tidak setuju, sederhana, setuju dan sangat setuju.

Perkara utama yang dilakukan sebelum mengedarkan soal selidik, pengkaji telah menghantar permohonan dan mendapatkan kelulusan untuk melakukan kajian selaras dengan etika penyelidikan yang telah digariskan oleh pihak universiti UKM (Etika Dan Amalan Cemerlang Akademik UKM, 2018). Bagi melaksanakan kajian ini pada musim pandemik, pengkaji menggunakan kaedah tinjauan soal selidik secara atas talian dengan menghantar pautan melalui aplikasi seperti e-mel, Whatsapp, 
Facebook dan Instagram. Penggunaan rangkaian laman sosial ini dilihat sebagai kaedah yang paling sesuai dengan keadaan semasa akibat pandemik COVID-19 yang membatasi pergerakan dan perjumpaan dengan responden secara bersemuka. Selain itu, responden yang mengembalikan soal selidik dengan lengkap dianggap sebagai persetujuan responden untuk terlibat sama dalam kajian ini. Soal selidik ini ditadbir menggunakan portal tinjauan dalam talian, Google form (perkhidmatan tinjauan dalam talian). Pengkaji memilih untuk mengedarkan pautan melalui laman sosial kerana lebih mudah dan mendapat respons dengan cepat seperti yang dikatakan oleh Srivastav et al. (2020), orang ramai lebih aktif dalam menggunakan laman sosial jika dibandingkan dengan kekerapan dalam memeriksa e-mel, walaupun pengkaji tetap menghantar pautan menggunakan e-mel.

Data dianalisis dengan menggunakan IBM Statistical Package for the Social Sciences (SPSS) versi 23. Data statistik deskriptif akan dikira untuk semua pemboleh ubah. Perbezaan jenis motivasi antara jantina akan dianalisis dengan menggunakan ujian t-bebas dan hubungan motivasi dan tahap aktiviti fizikal diperoleh dengan menggunakan ujian korelasi pearson.

\section{Hasil Kajian}

\section{Data Demografi Responden}

Bahagian A dalam borang soal selidik adalah berkaitan dengan latar belakang responden seperti jantina, umur, agama, bangsa, tahap pendidikan, pekerjaan pelajar dan pendapatan purata ibu bapa responden. Responden dikehendaki menandakan pada bahagian yang telah diarahkan. Kesemua data mengenai demografi responden ditunjukkan dalam jadual 1.

Jadual 1 merupakan hasil analisis deskriptif demografi pelajar-pelajar Pendidikan Sukan dan Rekreasi Universiti Kebangsaan Malaysia melibatkan frekuensi atau jumlah responden (n) berserta peratusan bagi setiap kategori jantina, umur, agama, bangsa, tahun pengajian, pekerjaan pelajar dan pendapatan ibu bapa. Dapatan kajian menunjukkan responden yang menjawab soal selidik ini terdiri daripada 103 orang pelajar lelaki $(50.5 \%)$ dan 101 orang perempuan $(49.5 \%)$.

Responden telah dibahagikan kepada 4 kumpulan umur iaitu 19-20 tahun, 21-22 tahun, 23-24 tahun dan 25-26 tahun. Didapati seramai 42 orang responden berumur antara 19-20 tahun (20.5\%), 72 orang responden berumur 21-22 tahun (35.3\%), 62 orang responden berumur 23-24 tahun (30.3\%) dan 28 orang responden berumur 25-26 tahun (13.8\%).

Daripada jumlah keseluruhan responden yang dipilih, seramai 178 orang pelajar (87.3\%) daripada Islam, 5 orang pelajar (2.5\%) daripada Buddha, 3 orang pelajar (1.5\%) daripada Cina, 18 orang pelajar $(8.8 \%)$ daripada Kristian dan tiada responden dari agama lain-lain.

Daripada 204 orang responden yang dipilih secara rawak ini, bangsa Melayu mencatat responden yang tertinggi dengan 163 orang pelajar (79.9\%), 6 orang pelajar (2.9\%) berbangsa Cina, 4 orang pelajar $(2.0 \%)$ berbangsa India dan 31 orang pelajar $(15.2 \%)$ berbangsa lain-lain.

Seramai 204 orang responden yang sedang mengikuti pengajian di Fakulti Pendidikan Universiti Kebangsaan Malaysia ini dipilih dalam kajian ini. Seramai 41 orang pelajar (20.1\%) daripada Tahun 1, Tahun 2 mencatat responden yang tertinggi dengan 59 orang pelajar (28.9\%), 47 orang pelajar (23.0\%) daripada Tahun 3 dan 57 orang pelajar (27.9\%) daripada Tahun 4.

Status pekerjaan responden dibahagikan kepada 4 kumpulan iaitu kerajaan, swasta, sendiri dan pelajar sepenuh masa. Seramai 24 orang responden (11.8\%) bekerja kerajaan, 18 orang responden $(8.8 \%)$ bekerja swasta, 19 orang responden $(9.3 \%)$ bekerja sendiri dan pelajar sepenuh masa mencatat responden yang tertinggi dengan 143 orang responden $(70.1 \%)$.

Maklumat pendapatan ibu bapa dikelaskan kepada 3 kumpulan iaitu B40 (RM3,860.00 ke bawah), M40 (RM3,860.00 - RM8,319.00) dan T20 (RM8,319 ke atas). Seramai 126 orang pelajar (61.8\%) 
DOI: https://doi.org/10.47405/mjssh.v6i8.963

ibu bapa berpendapatan dalam kumpulan B40 (RM3,860.00 ke bawah), 59 orang pelajar (28.9\%) ibu bapa berpendapatan dalam kumpulan M40 (RM3,860.00 - RM8,319.00) dan 19 orang pelajar (9.3\%) ibu bapa berpendapatan dalam kumpulan T20 (RM8,319 dan ke atas).

Jadual 1: Profil demografi responden

\begin{tabular}{|c|c|c|c|}
\hline Profil Responden & Kumpulan & Kekerapan (n) & Peratusan $(\%)$ \\
\hline \multirow{2}{*}{ Jantina } & Lelaki & 103 & 50.5 \\
\hline & Perempuan & 101 & 49.5 \\
\hline \multirow[t]{4}{*}{ Umur } & $19-20$ tahun & 42 & 20.5 \\
\hline & 21-22 tahun & 72 & 35.3 \\
\hline & 23-24 tahun & 62 & 30.3 \\
\hline & 25-26 tahun & 28 & 13.8 \\
\hline \multirow[t]{4}{*}{ Agama } & Islam & 178 & 87.3 \\
\hline & Buddha & 5 & 2.50 \\
\hline & Hindu & 3 & 1.50 \\
\hline & Kristian & 18 & 8.80 \\
\hline \multirow[t]{4}{*}{ Bangsa } & Melayu & 163 & 79.9 \\
\hline & Cina & 6 & 2.90 \\
\hline & India & 4 & 2.00 \\
\hline & Lain-lain & 31 & 15.2 \\
\hline \multirow[t]{4}{*}{ Tahun Pengajian } & Tahun 1 & 41 & 20.1 \\
\hline & Tahun 2 & 59 & 28.9 \\
\hline & Tahun 3 & 47 & 23.0 \\
\hline & Tahun 4 & 57 & 27.9 \\
\hline \multirow[t]{4}{*}{ Pekerjaan Pelajar } & Kerajaan & 24 & 11.8 \\
\hline & Swasta & 18 & 8.80 \\
\hline & Sendiri & 19 & 9.30 \\
\hline & Pelajar Sepenuh Masa & 143 & 70.1 \\
\hline \multirow[t]{3}{*}{ Pendapatan Ibu bapa } & $\begin{array}{l}\text { B40 (RM3,860.00 ke } \\
\text { bawah) }\end{array}$ & 126 & 61.8 \\
\hline & $\begin{array}{l}\text { M40 (RM3,860.00 - } \\
\text { RM8,319.00) }\end{array}$ & 59 & 28.9 \\
\hline & $\begin{array}{l}\text { T20 (RM8,319.00 ke } \\
\text { atas) }\end{array}$ & 19 & 9.30 \\
\hline
\end{tabular}

Jadual 2 menunjukkan dari jumlah keseluruhan responden yang dipilih. Seramai 103 orang pelajar atau 50.5 peratus (56 lelaki dan 47 perempuan) melakukan aktiviti fizikal 150 minit dan ke atas bagi aktiviti berintensiti sederhana (MPA), 34 orang pelajar atau 16.7 peratus (16 lelaki dan 18 perempuan) 1 - 149 minit seminggu (MPA) dan seramai 67 orang atau 32.8 peratus (31 lelaki dan 36 perempuan) tidak melakukan aktiviti fizikal berintensiti sederhana (MPA). Bagi aktiviti berintensiti tinggi (VPA) seramai 56 lelaki dan 34 orang perempuan pelajar melakukan selama 75 minit dan ke atas aktiviti manakala terdapat 8 orang atau 3.9 peratus (4 lelaki dan 4 perempuan) melakukan $1-74$ minit aktiviti VPA dan seramai 106 orang pelajar atau bersamaan 43 lelaki dan 63 perempuan tidak melakukan aktiviti VPA dalam seminggu. Selain itu, bagi aktiviti fizikal berintensiti sederhana ke tinggi (MVPA) juga dilaporkan. Bagi kumpulan rendah mencatat jumlah responden tertinggi dengan 125 orang pelajar atau 61.3 peratus (59 lelaki dan 66 perempuan), 69 orang pelajar memilih untuk beraktiviti sederhana bagi corak aktiviti (MVPA) (38 lelaki dan 31 perempuan) dan kumpulan tinggi mencatat jumlah responden terendah dengan 10 orang pelajar (6 lelaki dan 4 perempuan) bagi aktiviti fizikal bercorak MVPA. 
DOI: https://doi.org/10.47405/mjssh.v6i8.963

Jadual 2: Pecahan responden mengikut purata masa melakukan aktiviti fizikal

\begin{tabular}{ccccccc}
\hline Jenis Aktiviti Fizikal & $\begin{array}{c}\text { Bilangan } \\
\text { responde } \\
\mathbf{n}(\mathbf{L})\end{array}$ & $\begin{array}{c}\text { Peratus } \\
\text { an } \\
(\%)\end{array}$ & $\begin{array}{c}\text { Bilangan } \\
\text { responde } \\
\mathbf{n}(\mathbf{P})\end{array}$ & $\begin{array}{c}\text { Peratu } \\
\text { san } \\
(\%)\end{array}$ & $\begin{array}{c}\text { Keselur } \\
\text { uhan }\end{array}$ & $\begin{array}{c}\text { Peratu } \\
\text { san } \\
(\%)\end{array}$ \\
\hline
\end{tabular}

\begin{tabular}{|c|c|c|c|c|c|c|}
\hline \multicolumn{7}{|l|}{ Aktiviti Berintensiti } \\
\hline Tidak Melakukan Aktiviti & 16 & 15.5 & 18 & 17.8 & 34 & 16.7 \\
\hline 1-149 Minit & 56 & 54.4 & 47 & 46.5 & 103 & 50.5 \\
\hline 150 Minit Ke Atas & $\mathrm{n}=103$ & $100 \%$ & $\mathrm{n}=101$ & $100 \%$ & $\mathrm{~N}=204$ & $100 \%$ \\
\hline Jumlah & & & & & & \\
\hline $\begin{array}{l}\text { Aktiviti Berintensiti Tinggi } \\
\text { (VPA) }\end{array}$ & 43 & 41.6 & 63 & 62.4 & 106 & 52.0 \\
\hline Tidak Melakukan Aktiviti & 4 & 3.9 & 4 & 4.0 & 8 & 3.9 \\
\hline 1-74 Minit & 56 & 54.4 & 34 & 33.7 & 90 & 44.1 \\
\hline 75 Minit Ke Atas & & & & & & \\
\hline Jumlah & $\mathrm{n}=103$ & $100 \%$ & $\mathrm{n}=101$ & $100 \%$ & $\mathrm{~N}=204$ & $100 \%$ \\
\hline $\begin{array}{l}\text { Aktiviti Fizikal Berintensit } \\
\text { Sederhana Ke Tinggi } \\
\text { (MVPA) }\end{array}$ & & & & & & \\
\hline Rendah & 59 & 57.3 & 66 & 65.4 & 125 & 61.3 \\
\hline Sederhana & 38 & 36.9 & 31 & 30.7 & 69 & 33.8 \\
\hline Tinggi & 6 & 4.0 & 4 & 4.9 & 10 & 4.9 \\
\hline Jumlah & $\mathrm{n}=103$ & $100 \%$ & $\mathrm{n}=101$ & $100 \%$ & $\mathrm{~N}=204$ & $100 \%$ \\
\hline
\end{tabular}

Berdasarkan kepada jadual 3, kaedah analisis statistik menggunakan kaedah Ujian-t Sampel Bebas terhadap faktor motivasi intrinsik kesihatan dan kecergasan menunjukkan nilai $\mathrm{t}(202)=-0.28, \mathrm{p}=$ $0.78(\mathrm{P}>0.05)$ adalah tidak signifikan.

Tidak terdapat perbezaan yang signifikan antara jantina dengan faktor motivasi intrinsik pelajarpelajar Sukan dan Rekreasi Universiti Kebangsaan Malaysia. Ia menunjukkan bahawa faktor kesihatan dan kecergasan tidak mempengaruhi penglibatan pelajar dalam aktiviti fizikal berdasarkan jantina. Dapatan menunjukkan nilai min dan sisihan piawai bagi faktor kesihatan dan kecergasan bagi pelajar lelaki ( $\mathrm{M}=4.56, \mathrm{SP}=0.55)$ dan pelajar perempuan $(\mathrm{M}=4.58$, $\mathrm{SP}=0.52)$. Faktor minat dan keseronokan menunjukkan nilai $\mathrm{t}(202)=-1.24, \mathrm{p}=0.22(\mathrm{P}>0.05)$ adalah tidak signifikan. Tidak terdapat perbezaan yang signifikan di antara jantina dengan faktor motivasi intrinsik minat dan keseronokan pelajar-pelajar Sukan dan Rekreasi Universiti Kebangsaan Malaysia. Ia menunjukkan bahawa faktor minat dan keseronokan tidak mempengaruhi penglibatan pelajar dalam aktiviti fizikal berdasarkan jantina. Dapatan juga menunjukkan.. nilai min dan sisihan piawai bagi faktor minat dan keseronokan bagi pelajar lelaki $(\mathrm{M}=4.43, \mathrm{SP}=0.65)$ dan perempuan $(\mathrm{M}=4.31, \mathrm{SP}=0.73)$.

Berdasarkan kepada jadual 3, kaedah analisis statistik inferensi menggunakan kaedah Ujian-t Sampel Bebas terhadap faktor motivasi intrinsik kemahiran dan kepakaran menunjukkan nilai $t(202)=-1.46$, $\mathrm{p}=0.15(\mathrm{P}>0.05)$ adalah tidak signifikan. Tidak terdapat perbezaan yang signifikan antara jantina dengan faktor motivasi intrinsik pelajar-pelajar Sukan dan Rekreasi Universiti Kebangsaan Malaysia. Ia menunjukkan bahawa faktor kemahiran dan kepakaran tidak mempengaruhi penglibatan pelajar dalam aktiviti fizikal berdasarkan jantina. Dapatan juga menunjukkan nilai min dan sisihan piawai bagi faktor kemahiran dan kepakaran bagi pelajar lelaki ( $\mathrm{M}=4.29, \mathrm{SP}=0.76)$ dan perempuan $(\mathrm{M}=$ 4.14, $\mathrm{SP}=0.74)$. Faktor berkaitan tubuh badan menunjukkan nilai $\mathrm{t}(202)=-2.61, \mathrm{p}=0.10(\mathrm{P}>0.05)$ 
adalah tidak signifikan. Tidak terdapat perbezaan yang signifikan antara jantina dengan faktor motivasi intrinsik pelajar-pelajar Sukan dan Rekreasi Universiti Kebangsaan Malaysia. Ia menunjukkan bahawa faktor berkaitan tubuh badan tidak mempengaruhi penglibatan pelajar dalam aktiviti fizikal berdasarkan jantina. Dapatan menunjukkan nilai min dan sisihan piawai bagi faktor berkaitan tubuh badan bagi pelajar lelaki $(\mathrm{M}=4.53, \mathrm{SP}=0.61)$ dan perempuan $(\mathrm{M}=4.29, \mathrm{SP}=$ $0.74)$.

Jadual 3: Pecahan responden mengikut jenis motivasi intrinsik berdasarkan jantina

\begin{tabular}{|c|c|c|c|c|c|c|c|}
\hline Motif & Jantina & $\mathrm{n}$ & Min & $\begin{array}{l}\text { Sisihan } \\
\text { Piawai }\end{array}$ & Df & Nilai-t & Sig. \\
\hline $\begin{array}{c}\text { Kesihatan dan } \\
\text { Kecergasan }\end{array}$ & $\begin{array}{c}\text { Lelaki } \\
\text { Perempuan }\end{array}$ & $\begin{array}{l}103 \\
101\end{array}$ & $\begin{array}{l}4.56 \\
4.58\end{array}$ & $\begin{array}{l}0.55 \\
0.52\end{array}$ & 202 & -0.28 & 0.78 \\
\hline $\begin{array}{c}\text { Minat dan } \\
\text { Keseronokan }\end{array}$ & $\begin{array}{c}\text { Lelaki } \\
\text { Perempuan }\end{array}$ & $\begin{array}{l}103 \\
101\end{array}$ & $\begin{array}{l}4.43 \\
4.31\end{array}$ & $\begin{array}{l}0.65 \\
0.73\end{array}$ & 202 & -1.24 & 0.22 \\
\hline $\begin{array}{l}\text { Kemahiran } \\
\text { dan } \\
\text { Kepakaran }\end{array}$ & $\begin{array}{c}\text { Lelaki } \\
\text { Perempuan }\end{array}$ & $\begin{array}{l}103 \\
101\end{array}$ & $\begin{array}{l}4.29 \\
4.14\end{array}$ & $\begin{array}{l}0.76 \\
0.74\end{array}$ & 202 & -1.46 & 0.15 \\
\hline $\begin{array}{c}\text { Berkaitan } \\
\text { Tubuh Badan }\end{array}$ & $\begin{array}{c}\text { Lelaki } \\
\text { Perempuan }\end{array}$ & $\begin{array}{l}103 \\
101\end{array}$ & $\begin{array}{l}4.53 \\
4.29\end{array}$ & $\begin{array}{l}0.61 \\
0.74\end{array}$ & 202 & -2.61 & 0.10 \\
\hline
\end{tabular}

Berdasarkan kepada jadual 4, kaedah analisis statistik inferensi menggunakan kaedah Ujian-t Sampel Bebas terhadap faktor motivasi ekstrinsik keluarga menunjukkan nilai t $(202)=-0.58, \mathrm{p}=$ $0.56(\mathrm{P}>0.05)$ adalah tidak signifikan. Tidak terdapat perbezaan yang signifikan di antara jantina dengan faktor motivasi ekstrinsik pelajar-pelajar Sukan dan Rekreasi Universiti Kebangsaan Malaysia. Ia menunjukkan bahawa faktor keluarga tidak mempengaruhi penglibatan pelajar dalam aktiviti fizikal berdasarkan jantina. Dapatan juga menunjukkan nilai min dan sisihan piawai bagi faktor keluarga bagi pelajar lelaki ( $\mathrm{M}=4.17, \mathrm{SP}=0.77$ ) dan perempuan $(\mathrm{M}=4.11, \mathrm{SP}=0.85$ ). Faktor rakan-rakan menunjukkan nilai t $(202)=-0.55, \mathrm{p}=0.58(\mathrm{P}>0.05)$ adalah tidak signifikan. Tidak terdapat perbezaan yang signifikan di antara jantina dengan faktor motivasi ekstrinsik pelajar-pelajar Sukan dan Rekreasi Universiti Kebangsaan Malaysia. Ia menunjukkan bahawa faktor rakan-rakan tidak mempengaruhi penglibatan pelajar dalam aktiviti fizikal berdasarkan jantina. Dapatan juga menunjukkan nilai min dan sisihan piawai bagi faktor rakan-rakan bagi pelajar lelaki ( $\mathrm{M}=4.24, \mathrm{SP}=0.77)$ dan perempuan $(\mathrm{M}=4.18, \mathrm{SP}=0.89)$.

Jadual 4: Pecahan responden mengikut jenis motivasi ekstrinsik berdasarkan jantina

\begin{tabular}{cccccccc}
\hline Motif & Jantina & $\mathbf{n}$ & Min & $\begin{array}{c}\text { Sisihan } \\
\text { Piawai }\end{array}$ & Df & Nilai-t & Sig. \\
\hline Keluarga & Lelaki & 103 & 4.17 & 0.77 & 202 & -0.58 & 0.56 \\
& Perempuan & 101 & 4.11 & 0.85 & & & \\
Rakan-rakan & Lelaki & 103 & 4.24 & 0.77 & 202 & -0.55 & 0.58 \\
& Perempuan & 101 & 4.18 & 0.89 & & & \\
Kemudahan & Lelaki & 103 & 3.70 & 1.03 & 202 & -1.39 & 0.17 \\
fasiliti sukan & Perempuan & 101 & 3.89 & 0.95 & & & \\
Peranan & Lelaki & 103 & 4.30 & 0.74 & 202 & -1.31 & 0.90 \\
Universiti & Perempuan & 101 & 4.29 & 0.77 & & & \\
\hline
\end{tabular}


Berdasarkan kepada jadual 4, kaedah analisis statistik inferensi menggunakan kaedah Ujian-t Sampel Bebas terhadap faktor motivasi ekstrinsik kemudahan fasiliti sukan menunjukkan nilai t $(202)=-1.39$, $\mathrm{p}=0.17(\mathrm{P}>0.05)$ adalah tidak signifikan. Tidak terdapat perbezaan yang signifikan antara jantina dengan faktor motivasi ekstrinsik pelajar-pelajar Sukan dan Rekreasi Universiti Kebangsaan Malaysia. Ia menunjukkan bahawa faktor kemudahan fasiliti sukan tidak mempengaruhi penglibatan pelajar dalam aktiviti fizikal berdasarkan jantina. Dapatan juga menunjukkan nilai min dan sisihan piawai bagi faktor kemudahan fasiliti sukan bagi pelajar lelaki ( $\mathrm{M}=3.70, \mathrm{SP}=1.03)$ dan perempuan $(\mathrm{M}=$ $3.89, \mathrm{SP}=0.95)$. Faktor peranan Universiti menunjukkan nilai $\mathrm{t}(202)=-1.31, \mathrm{p}=0.90(\mathrm{P}>$ $0.05)$ adalah tidak signifikan. Tidak terdapat perbezaan yang signifikan di antara jantina dengan faktor motivasi ekstrinsik pelajar-pelajar Sukan dan Rekreasi Universiti Kebangsaan Malaysia. Ia menunjukkan bahawa faktor peranan universiti tidak mempengaruhi penglibatan pelajar dalam aktiviti fizikal berdasarkan jantina. Dapatan juga menunjukkan nilai min dan sisihan piawai bagi faktor peranan Universiti bagi pelajar lelaki ( $M=4.30, S P=0.74)$ dan perempuan $(M=4.29$, $\mathrm{SP}=0.77)$.

Jadual 5 adalah hasil keputusan ujian yang dijalankan. Keputusan mendapati bahawa terdapat korelasi antara faktor motivasi ekstrinsik dengan tahap penglibatan aktiviti fizikal pelajar-pelajar Sukan dan Rekreasi UKM dalam aktiviti fizikal. Faktor motivasi ekstrinsik dengan impak penglibatan pelajar ialah $(r=0.606, p<0.05)$. Pekali korelasi $r=0.606$ menunjukkan terdapat hubungan antara pemboleh ubah bersandar dan pemboleh ubah bebas, hubungannya sederhana. Selain itu, untuk faktor motivasi intrinsik dengan tahap penglibatan aktiviti fizikal pelajar ialah $(\mathrm{r}=0.24, \mathrm{P}>0.05)$ menunjukkan hubungan yang sangat lemah. Namun begitu, hanya satu pemboleh ubah iaitu faktor motivasi ekstrinsik adalah signifikan. Ini menunjukkan pemboleh ubah ini memberi kesan kepada penglibatan pelajar-pelajar Sukan dan Rekreasi UKM untuk melakukan aktiviti fizikal.

Jadual 5: Korelasi antara motivasi intrinsik dan ekstrinsik dan tahap aktiviti fizikal

\begin{tabular}{lcc} 
& Pemboleh ubah & Tahap motivasi \\
\hline Faktor intrinsik & 0.24 \\
Faktor ekstrinsik & 0.61 \\
\hline
\end{tabular}

*Signifikan pada aras keertian 0.05 (2-hujung)

\section{Perbincangan Kajian}

Kajian ini bertujuan untuk menilai tahap aktiviti fizikal serta faktor motivasi yang mempengaruhi pelajar SUKRES UKM untuk melibatkan diri dalam aktiviti fizikal semasa pandemik COVID-19. Kajian ini merupakan antara kajian terawal yang mengkaji faktor motivasi dan tahap aktiviti fizikal semasa pandemik dalam kalangan pelajar universiti di Malaysia. Hasil kajian mendapati bahawa majoriti pelajar SUKRES UKM tidak melakukan aktiviti fizikal secara aktif semasa pandemik dengan peratusan (61.3\%) bagi MVPA daripada keseluruhan jumlah responden. Bertepatan dengan kajian yang dijalankan oleh Puccinelli et al. (2021) yang mendapati pandemik COVID-19 telah mengakibatkan impak negatif ke atas aktiviti fizikal rakyat di Brazil. Bagi memenuhi ciri melakukan aktiviti fizikal secara aktif seharusnya seseorang individu perlu melakukan sekurang-kurangnya 70150 minit aktiviti berintensiti VPA atau 150-300 minit aktiviti MPA dalam seminggu menurut WHO (2019). Tahap aktiviti fizikal ini telah dikaitkan dengan beberapa faedah penjagaan kesihatan, termasuk risiko morbiditi dan kematian serta tahap kesihatan kardiovaskular yang lebih rendah (Puggina et al., 2018). Selain itu, tahap aktiviti fizikal yang lebih rendah kerana pengasingan sosial yang berterusan berpotensi meningkatkan risiko merosakkan sistem imun, pernafasan, kardiovaskular, muskuloskeletal serta menjejaskan kesihatan mental (Woods et al., 2020). Tahap imuniti badan yang rendah dan pelbagai masalah kesihatan yang lain adalah petanda yang tidak baik semasa berdepan dengan wabak pandemik COVID-19 ini. Walaupun SARS-CoV-2 akan menyerang fungsi organ paruparu yang utama, namun ianya juga akan menyebabkan kegagalan fungsi organ utama badan yang lain (Dhama et al., 2020). Oleh yang demikian, aktiviti fizikal berfungsi sebagai perisai yang dapat mengekang daripada terkena virus COVID-19 dan membantu meningkatkan kecergasan serta imuniti badan secara holistik. 
Pengekalan aktiviti fizikal dalam tempoh pandemik dilihat amat penting dan hal ini dipengaruhi oleh faktor motivasi individu. Regulasi dalaman atau motivasi intrinsik dikatakan lebih mendorong seseorang dalam ketekalan melakukan aktiviti fizikal bagi sesuatu tempoh yang panjang (Ahmad et al, 2020) berbanding faktor ganjaran atau insentif yang berbentuk hadiah mahupun persekitaran. Namun kajian ini melaporkan faktor motivasi ekstrinsik lebih menyumbang kepada penglibatan pelajar-pelajar Sukan dan Rekreasi UKM bagi pelajar perempuan dan pelajar lelaki lebih bermotivasi secara intrinsik walaupun tidak terdapat perbezaan yang signifikan bagi kedua-dua faktor motivasi berdasarkan jantina. Dalam pada itu, kajian oleh Ahmad et al. 2020 mendapati tidak terdapat perbezaan yang signifikan bagi kategori motivasi intrinsik dan ekstrinsik berdasarkan jantina. Sementara itu, kajian yang dijalankan oleh Wang H., et al, 2021 mencadangkan faktor kesungguhan bagi meneruskan penglibatan dalam aktiviti fizikal semasa COVID-19 bagi golongan dewasa China seperti cara mempelbagaikan kemahiran sukan, meningkatkan motivasi kendiri individu serta sokongan dari organisasi sukan tempatan. Cadangan ini dilihat bertepatan dengan isu yang sedang dialami oleh kebanyakan individu dan pelajar SUKRES UKM kerana mereka merasakan terdapat lebih banyak kekangan untuk beraktiviti fizikal semasa pandemik COVID-19 (Asmin S., 2020). Meskipun kajian ini tidak menunjukkan faktor motivasi intrinsik lebih mempengaruhi penglibatan dalam aktiviti fizikal semasa pandemik COVID-19 dan dapatan ini berbeza dengan dapatan yang dilaporkan sebelum pandemik, ketekalan bagi dapatan ini masih boleh dipersoalkan. Oleh itu, diharapkan lebih banyak kajian mengenai motivasi dan penglibatan dalam aktiviti fizikal semasa pandemik COVID-19 boleh dijalankan dan dapat menyumbang kepada ketekalan dapatan kajian ini.

Perkaitan atau hubungan antara motivasi intrinsik, ekstrinsik terhadap tahap aktiviti fizikal semasa pandemik COVID-19 turut diuji dalam kajian ini bagi menyokong dapatan kajian. Kajian ini mendapati terdapat hubungan antara motivasi ekstrinsik terhadap tahap penglibatan aktiviti fizikal semasa pandemik COVID-19. Memandangkan kajian ini hanya melibatkan responden pelajar Sukan dan Rekreasi UKM maka hubungan ini tidaklah dianggap bertentangan dengan dapatan kajian yang lain. Malah diharapkan terdapat lebih banyak kajian lanjutan dapat dijalankan menggunakan jenis soal selidik dan responden yang berbeza.

\section{Kesimpulan}

Kajian ini dijalankan adalah untuk mengkaji faktor motivasi intrinsik dan ekstrinsik serta tahap penglibatan pelajar Sukan dan Rekreasi Universiti Kebangsaan Malaysia dalam aktiviti fizikal semasa pandemik COVID-19. Keseluruhannya kajian ini menilai tahap penglibatan aktiviti fizikal pelajar seterusnya mengukur hubungan antara faktor motivasi terhadap tahap aktiviti fizikal pelajar. Hasil dapatan kajian ini dapat memberi maklumat dan data mengenai tahap aktiviti fizikal dan faktor motivasi dalam kalangan pelajar universiti awam Malaysia umumnya. Tahap penglibatan aktiviti fizikal yang rendah dalam kalangan pelajar menggambarkan pelajar kurang melakukan aktiviti fizikal semasa pandemik COVID-19 dan dalam perintah kawalan pergerakan PKP dan hal ini mengundang pelbagai impak negatif bukan sahaja kepada kesihatan malahan kesejahteraan hidup individu secara keseluruhannya.

Gaya hidup yang tidak sihat semasa pandemik COVID-19 ini boleh dijadikan sebagai penanda aras bagi institusi berkaitan dalam merencanakan inisiatif-inisiatif bagi mengubah corak gaya hidup ini. Penambahbaikan perlu dilaksanakan untuk menggalakkan masyarakat dalam melakukan aktiviti fizikal terutama semasa negara dilanda wabak penyakit pandemik. Selain itu, kajian ini mampu menambah pengetahuan asas masyarakat tentang peri penting melakukan aktiviti fizikal khususnya semasa pandemik dan menyedari akan lebih banyak peluang untuk beraktiviti semasa pandemik. Tegasnya, diharapkan dapatan ini dapat menyumbang kepada ketekalan kajian yang dijalankan semasa pandemik COVID-19 dan dapat membantu institusi berkaitan dalam negara menggalakkan masyarakat bagi meningkatkan aktiviti fizikal sama ada semasa atau di luar musim negara dilanda wabak bencana seperti pandemik COVID-19. 


\section{Rujukan}

Adarsh Kumar Srivastav, Neha Sharma \& Asir John Samuel (2020). Impact of Coronavirus disease 19 (COVID-19) lockdown on physical activity and energy expenditure among physiotheraphy professionals and students using web-based open E-survey sent through WhatsApp, Facebook and Instagram messengers. Clinical epidemiology and global health, $\quad 9, \quad 78-84$. DOI: https://doi.org/10.1016/j.cegh.2020.07.003

Anna Puggina, Katina Aleksovska, Christoph Buck, Con Burns, Greet Cardon, Angela Carlin, Simon Chantal, et al. (2018). Policy determinants of physical activity across the life course: a 'DEDIPAC' umbrella systemic literature review. European Journal of Public Health 28(1): 105118. DOI: https://doi.org/10.1093/eurpub/ckx174

C. Michael Hall, Daniel Scott \& Stefan Gossling (2020). Pandemics, transformations and tourism: be careful what you wish for. Tourism Geographies, 22:3, 577-598. DOI: $10.1080 / 14616688.2020 .1759131$

Edward L. Deci \& Richard M. Ryan (1985). Intrinsic motivation and self-determination in human $\begin{array}{lllll}\text { behaviour. } & \text { Springer } & \text { US, } & \text { 978-1-4899-2271-7: } & \text { XVI, }\end{array}$ DOI: $10.1007 / 978-1-4899-2271-7$.

Edward L. Deci \& Richard M. Ryan (2000). The "What" and "Why" of goal pursuits: human needs and the self-determination of behaviour. Psychological Inquiry 11:227-268.

Emerencia Ngah Y., Lyonga E., Ikomey F., Tembe Fokunang E., Eustace B., Mesembe M, Gilbert Ndeh D., et al. (2020). Curbing the spread of COVID-19 pandemic caused by SARS-CoV-2: considering psychological, socio-legal and ethical implications on preventive measures in Cameroon. International Journal of Biology and Genetics 3(1)-108. DOI: $10.31829 / 2692-4242 /$ biogen2020-3(1)-108

Grenita Hall, Deepika R. Laddu, Shane A. Phillips, Carl J. Lavie \& Ross Arena (2020). A tale of two pandemics: how will COVID-19 and global trends in physical inactivity and sedentary behaviour affect one another? Progress in Cardiovascular Disease, S0033-0620(20)30077-3. DOI: https://dx.doi.org/10.1016\%2Fj.pcad.2020.04.005

H. Douglas Brown (2006). Principles of language learning and teaching $5^{\text {th }}$ edition. White Plains, New York: Pearson Education.

Harold W. Kohl $3^{\text {rd }}$, Cora Lynn Craig, Estelle Victoria Lambert, Shigeru Inoue, Jasem Ramadan Alkandari, Grit Leetongin \& Sonja Kahlmeier (2012). The pandemic of physical inactivity: global action for public health. Lancet Physical Activity Series Working Group 380(9838): 294-305. DOI: 10.1016/S0140-6736(12)60898-8.

Huan Wang, Lianshi Feng, Yanfen Zhang, Fuhong Zhang, Jinmei Fu, Mei Wang, Dongming Wu, et al. (2021). Changes in Chinese adults' physical activity behavior and determinants defore and during the COVID-19 pandemic. Journal of Clinical Medicine 10, 3069. DOI: https://doi.org/10.3390/jcm10143069

Jacob E. Barkley, Andrew Lepp, Ellen Glickman, Greg Farnell, Jake Beiting, Ryan Wiet \& Bryan Dowdell (2020). The acute effects of the COVID-19 pandemic on physical activity sedentary Behaviour in University Students and Employees. International Journal Exercise Science 13(5), 1326-1339.

Jeffrey A. Woods, Noah T. Hutchinson, Scott K. Powers, William O. Roberts, Mari Carmen GomezCabrera, Zsolt Radak, Istvan Berkes, et al. (2020). The COVID-19 pandemic and physical activity. Sports Medicine and Health Science 2(2): 55-64. DOI: https://dx.doi.org/10.1016\%2Fj.smhs.2020.05.006

Joel Hellewell, Sam Abbot, Amy Gimma, Nikos I Bosse, Christopher I Jarvis, Timothy W Russell, et al. (2020). Feasibility of controlling COVID-19 outbreaks by isolation of cases and contacts. The Lancet Global Health Volume 8, Issue 4, E488-E496. DOI: https://doi.org/10.1016/S2214-109X(20)30074-7

Johannes Burtscher, Martin Burtscher \& Gregoire P. Millet (2020). (Indoor) isolation, stress and physical inactivity: Vicious circles accelerated by COVID-19? Scandinavian Journal of Medicine \& Science in Sports/Volume 30, Issue 8/ p. 1544-1545. https://doi.org/10.1111/sms.13706

Juhaizad Abdul Jalil \& Mohd Radzani Abdul Razak (2020). Motivasi dan penglibatan aktiviti fizikal dalam kalangan staf kolej Universiti Widad di Kuantan, Pahang. Jurnal Dunia Pendidikan, 
DOI: https://doi.org/10.47405/mjssh.v6i8.963

[S.l.], $\quad$ v. $\quad 2, \quad$ n. $\quad 1, \quad$ p. $204-214, \quad$ apr. Available at: <http://myjms.mohe.gov.my/index.php/jdpd/article/view/8929>. Date accessed: 22 june 2021.

Karley Geller, Kate Renneka, Sarah Custer \& Grace Tigue (2018). Self-determination theory, habitual behaviour, motivation, physical activity and maintenance. Sports Medicine International Open 2: E62-E66.DOI: https://doi.org/10.1055/a-0620-9137

Kuldeep Dhama, Sharun Khan, Ruchi Tiwari, Shubhankar Sircar, Sudipta Bhat, Yashpal Singh Malik, Karam Pal Singh, et al. (2020). Coronavirus disease 2019-COVID-19. National Library of Medicine 33(4): e00028-20.DOI: 10.1128/CMR.00028-20.

$\begin{array}{llllllll}\text { Malaysiakini.com. Diterbitkan } 16 & \text { Mac 2020. Diakses pada } 22 & \text { Jun } 2021 .\end{array}$ https://www.malaysiakini.com/news/514986

Marta Leyton-Roman, Ricardo de la Vega \& Jimenez-Castuera (2021). Motivation and commitment to sports practice during the lockdown caused by COVID-19. Movement Science and Sport Psychology.DOI: https://doi.org/10.3389/fpsyg.2020.622595

Martini Jamaris (2010). Orientasi baru dalam psikologi pendidikan. Sciences and Education Jakarta Pusat Yayasan Penamas Murni.

Mohamad Firdaus Ahmad, Siti Aida Lamat, S.M.P Sharifah Maimunah, Muhammad Wafi A.Rahman, Nur Dalilah Dahlan, Wahidah Tumijan \& Ummi Kalthum Mohd Mokhtar （2020). Motivasi intrinsik dan ekstrinsik dalam kalangan atlet Universiti Kebangsaan Malaysia. Jurnal Sains Sukan \& Pendidikan Jasmani, 9(1), 33-41. DOI: https://doi.org/10.37134/jsspj.vol9.1.5.2020

Paulo Jose Puccinelli, Taline Santos da Costa, Aldo Seffrin, Claudio Andre Barbosa de Lira, Rodrigo Luiz Vancini, Pantelis T. Nikolaidis, Beat Knechtle, Thomas Roseman, Lee Hill \& Marilia Santos Andrade (2021). Reduced level of physical activity during COVID-19 pandemic is associated with depression and anxiety levels: an internet-basedsurvey. BMC Public Health 21, 425. DOI: https://doi.org/10.1186/s12889-021-10470-Z

Richard M. Ryan, Christina M. Frederick, Deborah Lepes, Noel Rubio \& Kennon M. Sheldon (1997). Intrinsic motivation and exercise adherence. International Journal of Sport Psychology, 28(4), 335-354.

Shalizah Asmin, Mohd Radzani Abdul Razak \& Erwan Ismail (2021). Penglibatan aktiviti fizikal dan tahap indeks jisim badan dalam kalangan pelajar di fakulti pendidikan semasa pandemic COVID-19. $3^{\text {rd }}$ International Conference on Business, Education, Innovation and Social Sciences (ICBEISS 2021).

World Health Organization (2019). Global Action Plan on Physical Activity 2018-2030: More Active People for a Healthier World Geneva: World Health Organization. Diakses pada 18 Jun 2021. https://www.who.int/data/gho/publications/world-health-statistics

World Health Organization (2020). Events as they happen. Diakses pada 19 Jun 2021.https://www.who.int/emergencies/diseases/novel-coronavirus2019/events-as-theyhappen.

Zul Fadhli Abd Aziz \& Norlena Salamuddin (2018). Motivasi intrinsic dan ekstrinsik yang mempengaruhi penglibatan pelajar UKM untuk melakukan aktiviti fizikal. Politeknik \& Kolej Komuniti Journal of Social Sciences and Humanities, 3. 